\title{
FAKTOR-FAKTOR YANG MEMPENGARUHI PERSEPSI PENDIDIK TERHADAP PERMENDIKNAS NO 70 TAHUN 2009 MENGENAI PENDIDIKAN INKLUSIF
}

\author{
Hartika Putri Mutiarani, Kharisma Nasionalita
}

Prodi S1 Ilmu Komunikasi Fakultas Komunikasi dan Bisnis Universitas Telkom

\begin{abstract}
ABSTRAK
Penelitian ini di latarbelakangi oleh Permendiknas No.70 tahun 2009 mengenai pendidikan inklusif. Tujuan penelitian ini adalah untuk mengetahui faktor-faktor yang mempengaruhi persepsi pendidik SMP di Kabupaten Bekasi mengenai Permendiknas No 70 tahun 2009 mengenai pendidikan inklusif. Metodologi dalam penelitian ini bersifat eksplanatif dengan pendekatan kuantitatif. Teknik pengambilan sampel adalah purposive sampling dengan jumlah sampel 63 orang guru yang mengajar pada sekolah yang menyelenggarakan pendidikan inklusif. Dari hasil penelitian diperoleh gambaran bahwa faktor fungsional dan faktor struktutal memiliki pengaruh yang signifikan terhadap persepsi pendidik di Kabupaten Bekasi terhadap Permendiknas No 70 tahun 2009 mengenai Pendidikan Inklusif.
\end{abstract}

Kata Kunci: Faktor Yang Mempengaruhi Persepsi, Persepsi Permendiknas No 70 tahun 2009, Pendidikan Inklusif, Anak Berkebutuhan Khusus

\section{FACTORS THAT INFLUENCE THE PERCEPTION OF EDUCATION TOWARDS PERMENDIKNAS NUMBER 702009 ABOUT INCLUSIVE EDUCATION}

\begin{abstract}
The background of this research is about inclusive education on Permendiknas No 70 tahun 2009. The purpose of this research is to know factors that affected educators perception in junior high school about Permendiknas No 70 tahun 2009 about inclusive education. This research is explanative with quantitatif method. Sampling technique is purposive sampling with 63 samples of educators who teach at school that organize inclusive education. This research resulted that factor functional and factor structural have significant affect to perception of educators in Bekasi regency to Permendiknas No 70 tahun 2009 about inclusive education.
\end{abstract}

Keywords: Factors That Affected Perception, Perception, Permendiknas No 70 tahun 2009, Inclusive Education, Children with Special Needs

Korespondensi: Hartika Putri Mutiaharani. Universitas Telkom Jl. Telekomunikasi, Jl. Terusan Buah Batu No.01, Dayeuhkolot, Bandung, Jawa Barat 40257. Email: hartikapm@gmail.com 


\section{PENDAHULUAN}

Kejadian diskriminasi terhadap anak berkebutuhan khusus sering kali terjadi di Indonesia. Menurut Komnas HAM, anak berkebutuhan khusus yang merupakan bagian dari penyandang disabilitas masih mengalami diskriminasi berlapis. Kasus pelanggaran HAM yang dialami oleh penyandang disabilitas diantaranya adalah akses kepada pendidikan dan pekerjaan. Penyandang disabilitas masih seringkali ditolak untuk melanjutkan pendidikan ke jenjang perguruan tinggi karena alasan tidak tersedianya sarana dan prasarana penunjang pendidikan bagi mereka. Hal ini jelas sebuah tindak diskriminasi yang jelas-jelang melanggar HAM. Dalam bahasa lain, penyandang disabilitas mengalami diskriminasi yang berlapis (multiple discrimination) (Komnas Ham, 2016)

Banyak anak berkebutuhan khusus yang sering mendapat diskriminasi justru dari institusi pendidikan. Masih banyak institusi pendidikan yang menolak menerima keberadaan anak berkebutuhan khusus di sekolahnya. Salah satu contoh anak berkebutuhan khusus yang mendapatkan diskriminasi terdapat di daerah Bekasi. Seorang siswi berkebutuhan khusus kelas IX Sekolah Menengah Pertama diharuskan untuk mengundurkan diri dari sekolah tersebut jika orangtua murid tidak mendapatkan guru pendamping dalam batas waktu yang ditentukan (Harian Lokal Sentana, 2016). Hal ini bertentangan dengan program pemerintah untuk melaksanakan wajib belajar 9 tahun.

Hak untuk mendapatkan pendidikan adalah salah satu hak asasi manusia yang diatur dalam BAB XA tentang Hak Asasi Manusia dan juga merupakan hak dasar warga negara BAB XIII tentang Pendidikan dan Kebudayaan dalam UUD 1945 setelah amandemen. Pasal 28C ayat (1) menyatakan: "Setiap orang berhak mengembangkan diri melalui pemenuhan kebutuhan dasarnya, berhak mendapat pendidikan dan memperoleh manfaat dari ilmu pengetahuan dan tekhnologi, seni dan budaya, demi meningkatkan kualitas hidupnya dan demi kesejahteraan umat manusia."

Pendidikan sendiri berasal dari kata "didik", lalu kata ini mendapat awalan me sehingga menjadi "mendidik" artinya memelihara dan memberi latihan (Muhibbin Syah, 2008 : 10). Selanjutnya, pengertian pendidikan menurut Kamus Besar Bahasa Indonesia ialah proses perubahan sikap dan tata laku seseorang atau kelompok orang dalam usaha mendewasakan manusia melalui upaya pengajaran dan pelatihan.

Pendidikan adalah bagian dari upaya untuk memampukan setiap insan untuk mengembangkan potensi dirinya agar tumbuh menjadi manusia yang tangguh dan berkarakter serta berkehidupan sosial yang 
sehat. Dalam UUD 1945 pendidikan diarahkan bagi rakyat keseluruhan agar setiap warga dapat mengembangkan potensi diri yang merupakan pilar bagi perwujudan masyarakat yang adil dan sejahtera. Jika UUD 1945 itu dicermati maka mengikuti pendidikan adalah hak asasi bagi setiap orang dan bagi seluruh warga Negara Indonesia mengikuti pendidikan dasar adalah kewajiban dan menghalagi atau melarang anak Indonesia mendapatkan pendidikan merupakan perbuatan yang melanggar hukum dan ada sanksinya.

Selama ini, pendidikan bagi anak berkebutuhan khusus hanya ada di Sekolah Luar Biasa (SLB). Pada umumnya, lokasi SLB berada di Ibu Kota Kabupaten. Padahal anak-anak berkebutuhan khusus tersebar hampir diseluruh daerah (Kecamatan/ Desa) tidak hanya ada di Ibu Kota Kabupaten. Akibatnya, banyak anak berkebutuhan khusus, terutama yang kemampuan ekonomi orang tuanya lemah, terpaksa tidak disekolahkan karena lokasi SLB yang jauh dari rumah, sementara kalau ditempatkan di sekolah terdekat, sekolah tersebut tidak bersedia menerima, karena merasa tidak mampu melayaninya. Permasalahan di atas akan berakibat pada kegagalan program wajb belajar. Jumlah sekolah SMP/MTS di Kabupaten Bekasi berjumlah 288 lembaga dan 3 sekolah yang menerapkan pendidikan inklusif (Kementiran Pendidikan dan Kebudayaan Republik Indonesia, 2016).
Maka dari itu sebagai bentuk kepedulian pemerintah terhadap anak berkebutuhan khusus dan terwujudnya program wajib belajar, pemerintah menyelenggarakan pendidikan inklusif dengan mengeluarkan Peraturan Menteri Pendidikan Nasional Republik Indonesia Nomor 70 Tahun 2009 Tentang Pendidikan Inklusif (PENSIF) Bagi Peserta Didik Yang Memiliki Kelainan Dan Memiliki Potensi Kecerdasan Dan/ Atau Bakat Istimewa.

Pendidikan inklusif menurut Permendiknas No 70 tahun 2009 adalah sistem penyelenggaraan pendidikan yang memberikan kesempatan kepada semua peserta didik yang memiliki kelainan dan memiliki potensi kecerdasan dan/atau bakat istimewa untuk mengikuti pendidikan atau pembelajaran dalam satu lingkungan pendidikan secara bersama-sama dengan peserta didik pada umumnya. Menurut Permendiknas No 70 tahun 2009 tujuan dari penyelenggaraan pendidikan inklusif adalah memberikan kesempatan yang seluasluasnya kepada semua peserta didik yang memiliki kelainan fisik, emosional, mental, dan sosial atau memiliki potensi kecerdasan dan/atau bakat istimewa untuk memperoleh pendidikan yang bermutu sesuai dengan kebutuhan dan kemampuannya, serta mewujudkan penyelenggaraan pendidikan yang menghargai keanekaragaman, dan tidak diskriminatif bagi semua peserta didik. 
Walaupun sudah memiliki dasar hukum mengenai penyelenggaraan pendidikan inklusif, tetapi nyatanya masih terdapat hambatan yang terjadi. Hambatan penyelenggaraan pendidikan inklusif di Indonesia juga dipicu karena kebijakan yang diterapkan di suatu daerah itu akan dipersepsikan berbeda-beda karena banyak faktor-faktor yang mempengaruhi persepsi, sehingga antara daerah satu dan daerah lainnya akan menyelenggarakan pendidikan inklusif secara berbeda. Hal ini dibuktikan dengan adanya daerah yang sudah memiliki pokja untuk menyelenggarakan pendidikan inklusif dan ada daerah yang belum (Sumber: Hasil wawancara penulis bersama Pak Praptono hari Jumat, 2 September 2016 jam 10.00 WIB di Kantor Direktorat Pembinaan Pendidikan Khusus dan Layanan Khusus yang beralamat di Jalan RS Fatmawati, Jakarta).

Adapun fokus penelitian dalam penelitian ini adalah "Apa faktor-faktor yang mempengaruhi persepsi pendidik SMP di Kabupaten Bekasi terhadap permendiknas no 70 tahun 2009 mengenai pendidikan inklusif?"

\section{METODE PENELITIAN}

Peneliti menggunakan paradigma positivistik, positivistik merupakan penelitian dalam bidang ilmu-ilmu alam dan sosial yang menggunakan metode ilmiah dengan tingkat umum (Sulistyo, 2006:94).
Paradigma positivistik menganggap realitas itu sebagai sesuatu yang empiris atau benarbenar nyata dan dapat diobservasi. Penelitian ini menggunakan pendekatan kuantitatif dengan metode survey, desain penelitian yang digunakan adalah penelitian eksplanatif dan instrumen penelitian berupa kuesioner. Metode kuantitatif dapat diartikan sebagai metode penelitian yang berlandaskan pada filsafat positivisme, digunakan untuk meneliti pada populasi atau sampel tertentu, pengumpulan data menggunakan instrumen penelitian, analisis data bersifat kuantitatif/statistik, dengan tujuan untuk menguji hipotesis yang telah ditetapakan (Sugiyono, 2014:35-36). Sedangkan penelitian eksplanatif adalah penelitian untuk menunjukkan mengapa suatu kejadian atau gejala terjadi. Hasil akhir dari penelitian ini adalah gambaran mengenai hubungan sebab akibat (Bambang Prasetyo dan Lina Miftahul Jannah, 2011:43).

Subyek penelitian dalam penelitian ini adalah pendidik SMPN 1 Cikarang Utara dan pendidik SMPN 1 Cikarang Selatan, sedangkan obyek penelitian dalam penelitian adalah persepsi yang meliputi (1) Faktor fungsional: kebutuhan, pengalaman masa lalu, dan personal, (2) Faktor struktural: pikiran dan perasaan, (3) Atensi, (4) Interpretasi, (5) Empati.

Teknik pengumpulan data dengan melakukan survei kepada 63 responden dengan memberikan kuesioner. Kuesioner 
merupakan teknik pengumpulan data yang dilakukan dengan cara memberi seperangkat pertanyaan atau pernyataan tertulis kepada responden untuk dijawabnya (Sugiyono, 2014:230). Dalam penelitian ini, kuesioner diberikan kepada pendidik di SMPN 1 Cikarang Utara dan SMPN 1 Cikarang Selatan. Kuesioner ini digunakan untuk mendapatkan data yang berkaitan dengan faktor-faktor yang mempengaruhi persepsi pendidik terhadap permendiknas no 70 tahun 2009 mengenai pendidikan inklusif

\section{HASIL DAN PEMBAHASAN}

Dalam variabel faktor fungsional dapat diambil kesimpulan bahwa mayoritas responden yaitu pendidik setuju bahwa pendidikan inklusif dibutuhkan untuk mengembangkan potensi, minat dan bakat Anak Berkebuthan Khusus. Berdasarkan sub variable pengalaman masa lalu mayoritas responden setuju bahwa pendidik harus memiliki pengalaman berinteraksi dengan Anak Berkebutuhan Khusus dengan persentase total $87.6 \%$, sedangkan untuk pertanyaan dengan skor tertinggi kedua adalah pendidik harus memiliki pengalaman berinteraksi dengan terapis Anak Berkebutuhan Khusus. Hal ini dapat diambil kesimpulan bahwa pendidik setuju bahwa pendidikan inklusif merupakan tanggung jawab utama bagi pendidik, sehingga pendidik setuju untuk memiliki pengalaman berinteraksi dengan Anak Berkebutuhan
Khusus dan Terapis Anak Berkebutuhan Khusus untuk menyelenggarakan pendidikan inklusif. Untuk menghapus diskriminasi mayoritas responden setuju dengan persentase $87.3 \%$. bahwa pendidikan inklusif merupakan sistem pendidikan yang dibutuhkan untuk menghapus diskriminasi pendidikan terhadap Anak Berkebutuhan Khusus serta setuju dan mendukung penerapan pendidikan di seluruh sekolah di Indonesia dengan persentase $80.9 \%$.

Terdapat $22.2 \%$ responden yang ragu bahwa pendidikan inklusif telah sesuai dengan kebutuhan pendidikan Anak Berkebutuhan Khusus. Dapat diambil kesimpulan tanggapan responden terhadap faktor fungsional bahwa pendidik yang mayoritas memiliki pengalaman mengajar selama 10-20 tahun setuju bahwa pendidikan inklusif dibutuhkan untuk mengembangkan potensi, minat dan bakat Anak Berkebuthan Khusus tetapi terdapat sebagian kecil responden yang merasa bahwa pendidikan inklusif belum sesuai dengan kebutuhan Anak Berkebutuhan Khusus.

Dalam variabel faktor struktural dapat diambil kesimpulan bahwa mayoritas responden yaitu pendidik setuju bahwa Anak Berkebutuhan Khusus juga berhak mendapatkan pendidikan, dan untuk menyelenggarakan pendidikan inklusif agar terselenggara dengan baik maka pendidik setuju bahwa pendidikan inklusif harus mendapat dukungan penuh dari pihak-pihak 
yang terkait, yaitu pemerintah, sekolah, guru, serta orang tua peserta didik berkebutuhan khusus karena pendidikan inklusif merupakan bagian dari program kerja pemerintah dalam bidang pendidikan untuk mencerdaskan anak bangsa.

Terdapat $6.3 \%$ responden yang menjawab ragu dan $3.17 \%$ responden yang menjawab tidak setuju bahwa penggunaan kurikulum yang berbeda merupakan langkah yang tepat dalam penyelenggaraan pendidikan inklusif. Sehingga dapat diambil kesimpulan bahwa responden yaitu pendidik yang mayoritas berlatar belakang pendidikan $\mathrm{S}_{1}$ berpikir bahwa Anak Berkebutuhan Khusus berhak mendapatkan pendidikan, dan pendidikan tersebut dapat terselenggara dengan baik apabila mendapat dukungan penuh dari berbagai pihak, karena pendidikan inklusif ini merupakan bagian dari program kerja pemerintah, tetapi penggunaan kurikulum yang berbeda terhadap Anak Berkebutuhan Khusus bukan merupakan langkah yang tepat bagi sebagian kecil responden.

Untuk variabel persepsi pendidik terhadap Permendiknas No 70 tahun 2009 dengan sub variabel atensi dapat diambil kesimpulan bahwa mayoritas responden yaitu pendidik setuju dan memperhatikan kurikulum yang digunakan peserta didik berkebutuhan khusus sesuai dengan yang tertera di Pasal 7 yaitu:

"Satuan pendidikan penyelenggara pendidikan inklusif menggunakan kurikulum tingkat satuan pendidikan yang mengakomodasi kebutuhan dan kemampuan peserta didik sesuai dengan bakat, minat, dan minatnya."

Mayoritas responden juga setuju bahwa karakteristik belajar harus disesuaikan dengan peserta didik berkebutuhan khusus sesuai dengan yang tertera di pasal 8 yaitu:

"Pembelajaran pada pendidikan inklusif mempertimbangkan prinsip-prinsip pembelajaran yang disesuikan dengan karakteristik belajar peserta didik."

Serta mayoritas pendidik juga setuju untuk menerima bantuan tenaga professional dari pemerintah agar terciptanya pendidikan inklusif yang lebih optimal sesuai dengan yang tertera di Pasal 11 yaitu:

(1) Satuan pendidikan penyelenggara pendidikan inklusif berhak memperolah bantuan profesional sesuai dengan kebutuhan dari pemerintah kabupaten/kota. (2) Pemerintah, pemerintah daerah, dan/atau masyarakat dapat memberikan bantuan profesional kepada satuan pendidikan penyelenggara pendidikan inklusif.

(3) Bantuan profesional sebagaimana dimaksud pada ayat (2) dapat dilakukan melalui kelompok kerja pendidikan inklusif, kelompok kerja organisasi profesi, lembaga swadaya masyarakat, dan lembaga mitra terkait, baik dari dalam negeri maupun luar negeri.

(4) Jenis dukungan sebagaimana dimaksud pada ayat (4) dapat berupa:

a. bantuan profesional perencanaan, pelaksanaan, monitoring, dan evaluasi;

b. bantuan profesional dalam penerimaan, identifikasi dan asesmen, prevensi, intervensi, kompensatoris dan layanan advokasi peserta didik.

c. bantuan profesional dalam melakukan modifikasi kurikulum, program 
pendidikan individual, pembelajaran, penilaian, media, dan sumber belajar serta sarana dan prasarana yang asesibel.

(5) Satuan pendidikan penyelenggara pendidikan inklusif dapat bekerjasama dan membangun jaringan dengan satuan pendidikan khusus, perguruan tinggi, organisasi profesi, lembaga rehabilitasi, rumahsakit dan pusat kesehatan masyarakat, klinik terapi, dunia usaha, lembaga swadaya masyarakat (LSM), dan masyarakat.

Terdapat $14.3 \%$ responden yang ragu dan $6.4 \%$ responden yang tidak setuju bahwa peraturan ini sudah berjalan praktiknya sejak di tetapkannya Permendiknas No 70 tahun 2009 mengenai pendidikan inklusif ini sesuai dengan yang tertera di Pasal 15. Sehingga dapat diambil kesimpulan bahwa responden yaitu pendidik yang mayoritas berusia 41-50 tahun dan mayoritas pengalaman mengajar selama 10-20 tahun memperhatikan bahwa penggunaan kurikulum harus disesuaikan dengan karakteristik belajar peserta didik dan pemberian bantuan tenaga professional dapat menciptakan pendidikan inklusif yang lebih optimal, tetapi terdapat sebagian kecil responden yang memperhatikan bahwa peraturan yang mengatur pendidikan inklusif ini belum berjalan dengan baik praktiknya sejak ditetapkannya pada 5 Oktober 2009.

Untuk variabel persepsi pendidik terhadap Permendiknas No 70 tahun 2009 dengan sub variabel interpretasi dapat diambil kesimpulan bahwa mayoritas responden yaitu pendidik setuju dan memaknai bahwa pendidikan inklusif memberikan kesempatan yang sama kepada semua peserta didik, sesuai dengan yang tertera di Pasal 1:

"Dalam Peraturan ini, yang dimaksud dengan pendidikan inklusif adalah sistem penyelenggaraan pendidikan yang memberikan kesempatan kepada semua peserta didik yang memiliki kelainan dan memiliki potensi kecerdasan dan/atau bakat istimewa untuk mengikuti pendidikan atau pembelajaran dalam satu lingkungan pendidikan secara bersama-sama dengan peserta didik pada umumnya."

Mayoritas responden juga setuju dan memaknai bahwa sekolah yang menyelenggarakan pendidikan inklusif berhak memperoleh bantuan tenaga professional, sesuai dengan yang tertera di Pasal 11.

Serta mayoritas responden juga setuju dan memaknai bahwa pendidikan inklusif bertujuan untuk memberikan kesempatan yang sama dan mewujudkan penyelenggaraan pendidikan tidak diskriminatif, sesuai dengan yang tertera di Pasal 2 yaitu:

Pendidikan inklusif bertujuan :

(1) memberikan kesempatan yang seluas-luasnya kepada semua peserta didik yang memiliki kelainan fisik, emosional, mental, dan sosial atau memiliki potensi kecerdasan dan/atau bakat istimewa untuk memperoleh pendidikan yang bermutu sesuai dengan kebutuhan dan kemampuannya;

(2) mewujudkan penyelenggaraan pendidikan yang menghargai keanekaragaman, dan tidak 
diskriminatif bagi semua peserta didik sebagaimana yang dimaksud pada huruf a.

Terdapat $12.7 \%$ responden yang ragu, $1.6 \%$ responden yang tidak setuju dan $1.6 \%$ responden yang sangat tidak setuju dan memaknai bahwa dalam kegiatan belajar mengajar bisa masuk minimal satu peserta didik berkebutuhan khusus ke dalam rombongan belajar peserta didik normal, sesuai dengan yang tertera di Pasal 5 yaitu:

(1)Penerimaan peserta didik berkelainan dan/atau peserta didik yang memiliki potensi kecerdasan dan/atau bakat istimewa pada satuan pendidikan mempertimbangkan sumber daya yang dimiliki sekolah.

(2)Satuan pendidikan sebagaimana dimaksud dalam Pasal 4 ayat (1) mengalokasikan kursi peserta didik yang memiliki kelainan sebagaimana dimaksud dalam Pasal 3 ayat (1) paling sedikit 1 (satu) peserta didik dalam 1 (satu) rombongan belajar yang akan diterima.

(3)Apabila dalam waktu yang telah ditentukan, alokasi peserta didik sebagaimana dimaksud pada ayat (2) tidak dapat terpenuhi, satuan pendidikan dapat menerima peserta didik normal.

Hal ini dapat diambil kesimpulan bahwa mayoritas responden yaitu pendidik setuju dan memaknai bahwa pendidikan inklusif adalah pendidikan yang memberikan kesempatan dengan tujuan untuk menyelenggarakan pendidikan yang tidak diskriminatif kepada semua peserta didik. Pendidik juga setuju bahwa sekolah penyelenggara pendidikan inklusif berhak mendapatkan bantuan tenaga professional, tetapi terdapat sebagian kecil responden yang tidak setuju bahwa dalam kegiatan belajar mengajar bisa masuk minimal satu peserta didik berkebutuhan khusus ke dalam rombongan belajar peserta didik berkebutuhan khusus.

Untuk variabel persepsi pendidik terhadap Permendiknas No 70 tahun 2009 dengan sub variabel empati dapat diambil kesimpulan bahwa mayoritas responden setuju dan memahami terhadap Anak Berkebutuhan Khusus dengan kelainan fisik, emosional, mental, memiliki hak yang sama terhadap pendidikan, sesuai dengan yang tertera di Pasal 3 yaitu:

(1)Setiap peserta didik yang memiliki kelainan fisik, emosional, mental, dan sosial atau memiliki potensi kecerdasan dan/atau bakat istimewa berhak mengikuti pendidikan secara inklusif pada satuan pendidikan tertentu sesuai dengan kebutuhan dan kemampuannya.

(2)Peserta didik yang memiliki kelainan sebagaimana dimaksud dalam ayat (10 terdiri atas:

a. tunanetra;

b. tunarungu;

c. tunawicara;

d. tunagrahita;

e. tunadaksa;

f. tunalaras;

g. berkesulitan belajar;

h. lamban belajar;

i. autis;

j. memiliki gangguan motorik;

k. menjadi korban penyalahgunaan narkoba, obat terlarang, dan zat adiktif lainnya;

l. memiliki kelainan lainnya; m. tunaganda 
Mayoritas responden juga setuju dan memahami bahwa kurikulum yang digunakan oleh peserta didik berkebutuhan khusus harus disesuaikan dengan bakat dan minat peserta didik berkebutuhan khusus, sesuai dengan yang tertera di Pasal 7 yaitu:

"Satuan pendidikan penyelenggara pendidikan inklusif menggunakan kurikulum tingkat satuan pendidikan yang mengakomodasi kebutuhan dan kemampuan peserta didik sesuai dengan bakat, minat, dan minatnya."

Mayoritas responden juga setuju dan berempati terhadap Anak Berkebutuhan Khusus karena tujuan pendidikan inklusif untuk memaksimalkan potensi kecerdasan peserta didik berkebutuhan khusus, sesuai dengan yang tertera di Pasal 2 yaitu:

\section{Pendidikan inklusif bertujuan :}

(1) memberikan kesempatan yang seluas-luasnya kepada semua peserta didik yang memiliki kelainan fisik, emosional, mental, dan sosial atau memiliki potensi kecerdasan dan/atau bakat istimewa untuk memperoleh pendidikan yang bermutu sesuai dengan kebutuhan dan kemampuannya;

(2) mewujudkan penyelenggaraan pendidikan yang menghargai keanekaragaman, dan tidak diskriminatif bagi semиa peserta didik sebagaimana yang dimaksud pada hurufa.

Terdapat $1.6 \%$ responden yang ragu dan memahami adanya bantuan tenaga professional dapat membantu pendidik untuk memahami peserta didik berkebutuhan khusus, sesuai dengan yang tertera di Pasal 11.

Terdapat $14.3 \%$ responden yang ragu dan memahami bahwa Permendiknas No 70 tahun 2009 mulai berlaku sejak ditetapkan tanggal 5 Oktober 2009 oleh Menteri Pendidikan saat itu, sesuai yang tertera di Pasal 15.

Dapat diambil kesimpulan bahwa mayoritas responden yaitu pendidik setuju bahwa Anak Berkebutuhan Khusus dengan kelainan fisik, emosional dan mental memiliki hak yang sama terhadap pendidikan, dan pendidikan inklusif dibuat dengan tujuan untuk memaksimalkan potensi kecerdasan Anak Berkebutuhan Khusus, maka dari itu kurikulum yang digunakan harus disesuaikan dengan bakat dan minat peserta didik berkebutuhan khusus, tetapi terdapat sebagian kecil responden yang tidak memahami adanya bantuan tenaga professional yang diberikan oleh Pemerintah untuk membantu peserta didik berkebutuhan khusu dan sebagian kecil responden juga ragu dan tidak memahami bahwa Permendiknas No 70 tahun 2009 ini mulai berlaku sejak ditetapakan tanggal 5 Oktober 2009 oleh Menteri Pendidikan saat itu yaitu Bambang Sudibyo.

Faktor-faktor yang mempengaruhi persepsi pendidik yang terdiri atas faktor fungsional yang meliputi kebutuhan, pengalaman masa lalu dan personal individu, dan faktor struktural yang meliputi pikiran 
dan perasaan mempunyai pengaruh yang sangat kuat terhadap persepsi pendidik terhadap Permendiknas no 70 tahun 2009. Kuatnya pengaruh faktor fungsional dan faktor struktural terhadap persepsi pendidik di Kabupaten Bekasi terhadap Permendiknas no 70 tahun 2009 terkait dengan persepsi yang merupakan sebuah proses yang kompleks di mana individu memilih, mengatur, dan menafsirkan rangsangan sensoris menjadi gambaran yang bermakna dan koheren dengan dunia sekelilingnya (Berelson \& Steiner:1994, dalam Alo Liliweri, 2015:166). Persepsi merupakan proses internal yang dilalui individu dalam menyeleksi, dan mengatur stimuli yang datang dari luar. Setiap individu pastinya memiliki persepsi yang berbeda, karena persepsi adalah pengalaman tentang objek, peristiwa, atau hubungan yang diperoleh dengan menyimpulkan informasi dan menafsirkan pesan (Rakhmat:1994 dalam Alo Liliweri, 2015:167).

Faktor fungsional adalah faktor yang berasal dari kebutuhan, pengalaman masa lalu dan hal-hal lain yang termasuk apa yang kita sebut sebagai faktor-faktor personal. Faktor fungsional yang menentukan persepsi adalah obyek-obyek yang memenuhi tujuan individu yang melakukan persepsi. Yang menentukan persepsi bukan bentuk atau jenis stimuli tetapi karakteristik orang yang memberikan respon pada stimuli tersebut (Rakhmat, 2012:54). Dalam faktor fungsional dapat diambil kesimpulan bahwa mayoritas responden yaitu pendidik setuju bahwa pendidikan inklusif dibutuhkan untuk mengembangkan potensi, minat dan bakat Anak Berkebuthan Khusus.

Faktor struktural adalah faktor-faktor yang berasal semata-mata dari sifat stimulus fisik terhadap efek-efek syaraf yang ditimbulkan pada sistem saraf individu. Faktor-faktor struktural yang menentukan persepsi menurut teori Gestalt bila kita ingin memahami suatu peristiwa kita tidak dapat meneliti faktor-faktor yang terpisah tetapi memandangnya dalam hubungan keseluruhan (Rakhmat, 2012:57). Dalam faktor struktural dapat diambil kesimpulan bahwa mayoritas responden yaitu pendidik yang mayoritas berlatar belakang pendidikan $\mathrm{S}_{1}$ setuju bahwa Anak Berkebutuhan Khusus juga berhak mendapatkan pendidikan, dan untuk menyelenggarakan pendidikan inklusif agar dapat terselenggara dengan baik maka pendidik setuju bahwa pendidikan inklusif harus mendapat dukungan dari pihak-pihak yang terkait, yaitu pemerintah, sekolah, guru, serta orang tua peserta didik berkebutuhsn khusus karena pendidikan inklusif merupakan bagian dari program kerja pemerintah dalam bidang pendidikan untuk mencerdaskan anak bangsa tetapi penggunaan kurikulum yang berbeda terhadap Anak Berkebutuhan Khusus bukan merupakan langkah yang tepat bagi sebagian kecil responden. 
Persepsi merupakan inti dari Permendiknas No 70 tahun 2009 mengenai komunikasi, karena persepsi dapat pendidikan inklusif.

mengarahkan perilaku individu dan Berdasarkan hasil penelitian merupakan proses yang membantu kita terhadap sub variable interpretasi dapat dalam untuk medefinisikan dunia sekeliling diambil kesimpulan bahwa mayoritas (Alo Liliweri, 2015:169). Dalam penelitian responden yaitu pendidik setuju dan ini peneliti melakukan penelitian mengenai memaknai bahwa pendidikan inklusif Persepsi pendidik melalu tiga sub variable, memberikan kesempatan yang sama kepada yaitu: atensi, interpretasi dan empati. semua peserta didik, sesuai dengan yang Menurut James (dalam Solso, Maclin \& tertera di Pasal 1 Permendiknas No 70 tahun Maclin, 2007) atensi adalah pemusatan pikiran dalam bentuk yang jernih dan gambling, terhadap sejumlah objek simultan atau sekelompok pikiran. Pemusatan kesadaran adalah intisari dari atensi.

Berdasarkan hasil penelitian 2009 mengenai pendidikan inklusif., mayoritas responden juga setuju dan memaknai bahwa pendidikan inklusif bertujuan untuk memberikan kesempatan yang sama dan mewujudkan penyelenggaraan pendidikan tidak terhadap sub variable atensi dapat diambil diskriminatif, sesuai dengan yang tertera di kesimpulan bahwa mayoritas responden Pasal 2 Permendiknas No 70 tahun 2009 yaitu pendidik setuju dan memperhatikan mengenai pendidikan inklusif. dan mayoritas kurikulum yang digunakan peserta didik berkebutuhan khusus sesuai dengan yang tertera di Pasal 7 Permendiknas No 70 tahun 2009 mengenai pendidikan inklusif., Mayoritas responden juga setuju bahwa karakteristik belajar harus disesuaikan dengan peserta didik berkebutuhan khusus sesuai dengan yang tertera Pasal 8 Permendiknas No 70 tahun 2009 mengenai pendidikan inklusif. dan mayoritas pendidik juga setuju untuk menerima bantuan tenaga professional dari pemerintah agar terciptanya pendidikan inklusif yang lebih optimal sesuai dengan yang tertera di Pasal 11 responden juga setuju dan memaknai bahawa sekolah yang menyelenggarakan pendidikan inklusif berhak memperoleh bantuan tenaga professional, sesuai dengan yang tertera di Pasal 11 Permendiknas No 70 tahun 2009 mengenai pendidikan inklusif.

Wiryanto (2008:39) merangkum beberapa definisi mengenai empati. Freud (1992) empati dianggap sebagai memahami orang lain yang tidak mempunyai arti emosional bagi kita, Scotland (1978) sebagai keadaan ketika pengamat bereaksi secara emosional karena ia menanggapi orang lain mengalami atau siap mengalami suatu emosi. Berdasarkan hasil penelitian terhadap sub 
variabel empati dapat diambil kesimpulan bahwa mayoritas responden juga setuju dan berempati terhadap Anak Berkebutuhan Khusus karena tujuan pendidikan inklusif untuk memaksimalkan potensi kecerdasan peserta didik berkebutuhan khusus, sesuai dengan yang tertera di Pasal 2 Permendiknas No 70 tahun 2009 mengenai pendidikan inklusif. mayoritas responden setuju dan memahami terhadap Anak Berkebutuhan Khusus dengan kelainan fisik, emosional, mental, memiliki hak yang sama terhadap pendidikan, sesuai dengan yang tertera di Pasal 3 Permendiknas No 70 tahun 2009 mengenai pendidikan inklusif., dan mayoritas responden juga setuju dan memahami bahwa kurikulum yang digunakan oleh peserta didik berkebutuhan khusus harus disesuaikan dengan bakat dan minat peserta didik berkebutuhan khusus, sesuai dengan yang tertera di Pasal 7 Permendiknas No 70 tahun 2009 mengenai pendidikan inklusif.

\section{SIMPULAN}

Faktor fungsional dan faktor struktural berpengaruh signifikan terhadap persepsi pendidik terhadap Permendiknas No 70 tahun 2009 mengenai pendidikan inklusif.

Saran dari penelitian ini adalah agar penelitian selanjutnya dapat meneliti faktorfaktor yang mempengaruhi persepsi selain menggunakan teori Krech dan Crutcfield, salah satunya dengan menggunakan faktor- faktor yang mempengaruhi persepsi menurut Muchlas yaitu pelaku persepsi, obyek persepsi dan situasi. Saran selanjutnya adalah agar penelitian selanjutnya menggunakan metode mix method yaitu tidak hanya menggunakan metode penelitian kuantitatif tetapi dilengkapi juga dengan metode penelitian kualitatif melalui in depth interview agar dapat hasil jawaban responden yang lebih mendalam.

\section{DAFTAR PUSTAKA}

Basuki, Sulistyo. (2006). Metode Penelitian. Jakarta: Wedatama Widya Sastra

Liliweri, Alo. (2015). Komunikasi Antar Personal. Jakarta: Kencana

Prasetyo, Bambang \& Lina Miftahul Jannah. (2011). Metode Penelitian

Kuantitatif. Jakarta: PT Raja Grafindo

Rakhmat, Jalaluddin. (2012). Psikologi Komunikasi. Bandung: Remaja Rosdakarya.

Solso, L.R., Maclin, H. O \& Maclin M. K. (2007). Psikologi Kognitif Edisi

Kedelapan. Jakarta: Erlangga

Sugiyono. (2011). Metode Penelitian Pendidikan. Bandung: Alfabeta.

Sugiyono. (2014). Metode Penelitian Manajemen. Bandung: Alfabeta.

Syah, Muhibbin. (2008). Psikologi Pendidikan. Jakarta: Rajawali Pers

Wiryanto. (2008). Pengantar Ilmu

Komunikasi. Jakarta: PT Grasindo

Dede. 2016. "Liput Diskriminasi SMP Amanah Bangsa". Sentana, 25 Juli 2016

Kementrian Pendidikan dan Kebudayaan Republik Indonesia. 2016. Diakses dari http://dapo.dikdasmen.kemdikbud.go.i d/sekolah/6AC86A87D2EAFCCA0D9 C

Komnas Ham. 2016. Penyandang Dissabilitas Masih Mengalami 
Diskriminasi Berlapis. Diakses dari https://www.komnasham.go.id/index.p $\mathrm{hp} /$ news/2016/02/27/85/penyandangdissabilitas-masih-mengalamidiskriminasi-berlapis.html

Permendiknas No 70 tahun 2009 Mengenai Pendidikan Inklusif 